\title{
PRELIMINARY ASSESSMENT OF HEAVY METAL LEVELS IN MYTELLA FALCATA (BIVALVIA, MYTILIDAE) FROM BACANGA RIVER ESTUARY, SÃO LUÍS, STATE OF MARANHÃO, NORTHEASTERN BRAZIL
}

\author{
CARVALHO, G. P. de, CAVALCANTE, P. R. S., CASTRO, A. C. L. de and \\ ROJAS, M. O. A. I. \\ Departamento de Oceanografia e Limnologia da Universidade Federal do Maranhão, Largo dos Amores, \\ CEP 65020-240, São Luís, MA, Brazil \\ Correspondence to: Gabrielle Pinto de Carvalho, Departamento de Oceanografia e Limnologia, LABONIDRO, \\ Universidade Federal do Maranhão, Praça Gonçalves Dias, 21, Centro, CEP 65020-240, São Luís, MA \\ Received September 8, 1998 - Accepted December 8, 1998 - Distributed February 28, 2000
}

(With 1 figure)

\begin{abstract}
The concentrations of $\mathrm{Cu}, \mathrm{Zn}, \mathrm{Pb}$, and $\mathrm{Cd}$ were determined in the mussel Mytella falcata from the Bacanga River estuary, in order to evaluate the potential role of domestic effluents released "in natura" on the quality of the estuarine environment with consequences to shellfish resources. $\mathrm{Cu}$ concentrations ranged from $5.2 \mathrm{mg} . \mathrm{g}^{-1}$ to $13.1 \mathrm{mg} . \mathrm{g}^{-1}$, while $\mathrm{Zn}$ concentrations ranged from $49.1 \mathrm{mg} \cdot \mathrm{g}^{-1}$ to $76.3 \mathrm{mg} \cdot \mathrm{g}^{-1} . \mathrm{Pb}$ and $\mathrm{Cd}$ showed concentrations lower than $2 \mathrm{mg} \cdot \mathrm{g}^{-1}$. The results showed low concentrations of $\mathrm{Cu}, \mathrm{Pb}$ and $\mathrm{Cd}$ in the filter-feeding Mytella falcata in the study area in comparison with the maximum values stablished to foods by the Brazilian Government (Decree Law № 55,871). Finally, Zn presented slightly higher values than the maximum ones stablished by the Brazilian government.
\end{abstract}

Key words: heavy metals, bivalves, Mytella falcata, estuary, pollution

\section{RESUMO}

Avaliação preliminar dos níveis de metais-pesados em Mytella falcata (Bivalvia, Mytilidae) do estuário do rio Bacanga, São Luís, Estado do Maranhão, Nordeste do Brasil

Foram medidas as concentrações de $\mathrm{Cu}, \mathrm{Zn}, \mathrm{Pb}$ e $\mathrm{Cd}$ em moluscos bivalves da espécie Mytella falcata do estuário do Rio Bacanga, a fim de avaliar uma possível influência do lançamento de esgotos domésticos "in natura" na qualidade deste recurso estuarino. As concentrações de $\mathrm{Cu}$ variaram entre 5,2 mg.g ${ }^{-1}$ e 13,1 mg.g ${ }^{-1}$, enquanto para o Zn estes valores situaram-se entre 49,1 mg.g $\mathrm{g}^{-1}$ e 76,3 $\mathrm{mg} \cdot \mathrm{g}^{-1}$. O Pb e o Cd apresentaram valores muito baixos, inferiores a $2 \mathrm{mg} \cdot \mathrm{g}^{-1}$. Os resultados indicaram baixas concentrações para o $\mathrm{Cu}, \mathrm{Pb}$ e $\mathrm{Cd}$ nos exemplares de Mytella falcata para a área estudada, quando comparadas com os valores máximos estabelecidos pelo Governo Brasileiro (Decreto Lei № 55.871) para alimentos destinados ao consumo humano. O Zn porém, apresentou valores ligeiramente mais elevados que o máximo recomendável.

Palavras-chave: metais pesados, bivalves, Mytella falcata, estuário, poluição. 


\section{INTRODUCTION}

The indiscriminate release of "in natura" domestic sewage, constitutes one of the main factors of degradation of aquatic ecosystems located near major urban centers, and may contribute to the increase of the concentrations of the heavy metals in these environments. The Bacanga River estuary, located in the West of the island of São Luís ( $2^{\circ} 33^{\prime}$ S and $44^{\circ} 27^{\prime} \mathrm{W}$ ), receives a considerable load of domestic effluents from dense populated residencial areas of São Luís city and from residential settlements in its watershed, such as Parque Timbira, Parque dos Nobres and Parque Amazonas (Fig.1). Although submitted to strong anthropogenic pressure, the Bacanga River estuary still presents relatively rich aquatic fauna, composed of a varity of species of fish and molluscs, from which stands out Mytella falcata (Bivalvia, Mytilidae), known popularly as sururu. Due to its abundance and easy collection, this species is heighly consumed by the local population. Due to their filter-feeding and sedentary habits, they tend to present larger concentrations of heavy metals relative to migrating species (Castro, 1991); therefore they are excellent bioindicators heavy metals pollution.

Juras (1985), reported preliminary results on heavy metals in estuarine organisms of the Southwest zone of São Luís. The fishes Genyatremus luteus, Arius herzbergii and Mugil curema, and the bivalves Mytella falcata were analyzed, and the higher levels of $\mathrm{Hg}, \mathrm{Pb}, \mathrm{Cu}, \mathrm{Zn}$ and $\mathrm{Cd}$ found in the tissues of the molluscs.

Cavalcante et al. (1990), reported on the $\mathrm{Hg}$ distribution in sediments, estuarine water, and in biota, namely Mytella falcata (sururu) and Crassostrea rhizophorae (oyster-of-mangrove), collected along the rivers Mearim, Itapecuru and Cachorros, at São Marcos and Arraial Bays, as well as in the Coqueiro and Mosquitos straits.

The aquatic organisms are responsible for a great deal of recycling of metals retained in abiotic compartments of the ecosystem and consequently, they constitute the main pathway of export of heavy metals from the aquatic environment to the terrestrial through the food chain, by which they reach human beings (Fowler in Pfeiffer et al., 1985).

The lack of technical and scientific information that indicate the degree of quality of the local bodies of water, associated with the physiological and ecological characteristics of the species Mytella falcata, justify the development of this study. The main objective of this project is to determine the concentrations of $\mathrm{Cu}, \mathrm{Pb}, \mathrm{Zn}$ and $\mathrm{Cd}$ in these organisms and correlate their concentrations with biometric characteristics.

\section{MATERIAL AND METHODS}

Specimens of Mytella falcata were collected between September and October 1996, in the banks close to the points of release of domestic sewage in the area of the Bacanga estuary. The individuals were washed with estuarine water, packed in plastic bag and taken to the laboratory where they were separated by size, forming 3 groups of fifty individuals each: "P" (28.0-30.5 $\mathrm{mm}$ in length), "M" (38.0-40.0 mm) and "G" (51.0-55.2 mm), representing small, medium and large animals, respectively.

From each group, thirty individuals were selected to collect biometric data, such as: height, width and length ( $\mathrm{mm}$ ) and weight $(\mathrm{g})$. Following, the animals had their muscle tissues removed and weighed, in order to form at least five replicates, of approximately $4.0 \mathrm{~g}$ each. The samples were oven dried $\left(24 \mathrm{~h}, 105^{\circ} \mathrm{C}\right)$, for the determination of the dry weight (generally around one gram) and digested with a mixture of $\mathrm{HNO}_{3}$ (acid nitric) + $\mathrm{H}_{2} \mathrm{O}$ (1:1) and $150 \mu \mathrm{L} \mathrm{C}_{8} \mathrm{H}_{18} \mathrm{O}$ (octhanol), in a block digestor.

The extracts were analised for of $\mathrm{Cu}, \mathrm{Pb}$ and Cd by Potentiometric Stripping and Zn by Atomic Absorption Spectrophotometry (Talbot, 1983; Jagner \& Aren, 1979; Jagner, 1982; Cavalcante et al., 1994). The results of the analytical determinations of the replicates were expressed in dry weight. In order to test significant difference in the analysed group, Friedman's nonparametric statistical test was conducted.

\section{RESULTS AND DISCUSSION}

The Tables 1 and 2 show, the concentrations of metals in the shellfish from the Bacanga River estuary, compared with literature data. Average $\mathrm{Cu}$ concentration is $7.3 \mathrm{mg} . \mathrm{g}^{-1}$; which is very low compared to the maximum value $30.0 \mathrm{mg} \cdot \mathrm{g}^{-1}$, established to foods by the Brazilian Government (Decree Law № 55,871). 
Escala - 1:1000

\section{$\begin{array}{llllll}1 \mathrm{~km} & 0 & 1 & 2 & 3 & 4 \mathrm{~km}\end{array}$}

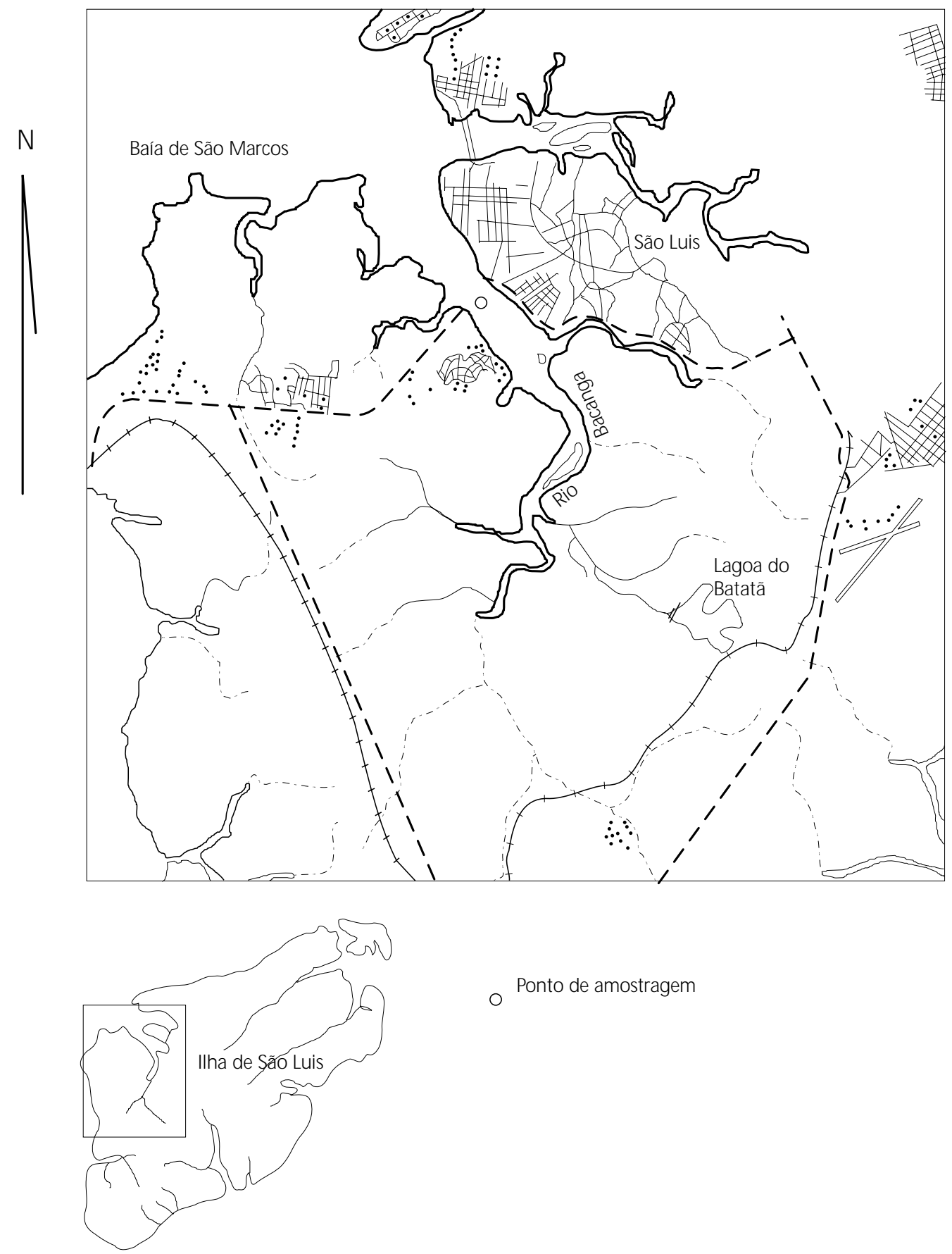

Fig. 1 - Map showing the location of studied area. 
TABLE 1

Concentration of heavy metals in Mytella falcata from the Bacanga River. Range of the concentrations (A), mean concentration $(x)$ and standard deviation (s) with results in $\mathrm{mg}^{-1} \mathrm{~g}^{-1}$ (dry weight).

\begin{tabular}{|c|c|c|c|c|}
\hline $\begin{array}{l}\text { SAMPLE LOT } \\
\text { (LENGTH mm) }\end{array}$ & $\begin{array}{c}\mathrm{Cu} \\
(\mathbf{3 0 . 0})^{*}\end{array}$ & $\begin{array}{c}\mathrm{Zn} \\
(\mathbf{5 0 . 0})^{*}\end{array}$ & $\begin{array}{c}\mathrm{Pb} \\
(2.0)^{*}\end{array}$ & $\begin{array}{c}\text { Cd } \\
(1.0)\end{array}$ \\
\hline $\begin{array}{l}\text { Small Lot } \\
(28.0-30.51)\end{array}$ & $\begin{array}{c}\mathrm{A}=5.2-8.4 \\
\times=7.4 \\
\mathrm{~s}=1.3\end{array}$ & $\begin{array}{c}\mathrm{A}=58.2-66.3 \\
\times=60.6 \\
\mathrm{~s}=3.3\end{array}$ & $<1.0$ & $<1.0$ \\
\hline $\begin{array}{l}\text { Medium Lot } \\
(38.12-39.90)\end{array}$ & $\begin{array}{c}\mathrm{A}=6.1-9.3 \\
\times=7.4 \\
\mathrm{~s}=1.6\end{array}$ & $\begin{array}{c}\mathrm{A}=49.1-58.5 \\
\times=52.5 \\
\mathrm{~s}=3.7\end{array}$ & $<1.0$ & $<1.0$ \\
\hline $\begin{array}{l}\text { Large Lot } \\
(51.0-55.20)\end{array}$ & $\begin{array}{c}\mathrm{A}=6.7-13.1 \\
\times=7.2 \\
\mathrm{~s}=2.6\end{array}$ & $\begin{array}{c}\mathrm{A}=49.3-76.3 \\
\times=56.0 \\
\mathrm{~S}=11.6\end{array}$ & $<1.0$ & $<1.0$ \\
\hline
\end{tabular}

Compared to values of previous studies in the area (Juras, 1985), the concentrations of $\mathrm{Cu}$ in our study are very low, and very similar to the concentration in the mussel Perna perna, from Rio de Janeiro State (Neira et al., 1995).

In spite of $\mathrm{Cu}$ being an important component in the blood of invertebrates, responsible for hemocyanine synthesis and oxygen transport (Aragão, 1995; Eysink, 1988) and a good indicator of urban effluents discharge (Neira et al., 1995), its concentrations in the samples are low. These values are comparable to those found in other pristine Brazilian coastal areas.

Lead concentrations are lower than 1.0 mg. $\mathrm{g}^{-1}$, being more than 20 times lower than maximum permited values for human consumption $\left(20 \mathrm{mg} \cdot \mathrm{g}^{-1}\right)$. Previous data by Juras (1988) from the straits of Coqueiro and Mosquitos $\left(<5,0 \mathrm{mg} \cdot \mathrm{g}^{-}\right.$ $\left.{ }^{1}\right)$ are similar to our study. In a general way, $\mathrm{Pb}$ is not concentrated in the marine biota even when its concentration in the sediments is high (Philipps in Pfeiffer et al., 1985).

On the other hand, human populations in general, are much more exposed to atmospheric lead, which represents the most important pathway to humans (Bernhard \& Zattera, 1973 in Pfeiffer, et al., 1985).

Also, as the presented values are similar to those found by Neira, et al. (1995) in mussels from non polluted areas of the SE Brazilian coast, it can be affirmed the study area is less affected by $\mathrm{Pb}$ pollution.

The concentrations of $\mathrm{Zn}$ ranged from 58.5 to $76.3 \mathrm{mg} \cdot \mathrm{g}^{-1}$, are slightly higher than the maximum values stablished to foods by the Brazilian Government (50.0 mg. $\mathrm{g}^{-1}$ ) (Decree Law № 55,871), and are considerably lower than that found by Lima et al. (1986), in C. brasiliana from the Sepetiba Bay area in the Southern Rio de Janeiro coast, considered to be a receiver of effluents from the industrial Zone of Santa Cruz. Juras (1985), found concentrations of $\mathrm{Zn}$ between 68.0 mg. $\mathrm{g}^{-1}$ and $105.0 \mathrm{mg} . \mathrm{g}^{-1}$ in Mytella falcata from the straits of the Coqueiro and Mosquitos, values that are higher than our data.

These results are apparently due to the fact that Zinc is essential element in these organism's metabolism, besides this metal be usually associated, in aquatic environments, with suspended particles which are used by mussels in their filter-feeding diet (Moore \& Rammoorthy, 1984).

Similarly to Lead, the levels for Cadmium were inferior to $1 \mathrm{mg} \cdot \mathrm{g}^{-1}$ and similar concentration found in Mytella falcata from the straits of Coqueiro and Mosquitos $\left(<0,5 \mathrm{mg} \cdot \mathrm{g}^{-1}\right)$ observed by Juras (1985), which is indicating that Cadmium is not contaminated in the study area.

The results of the statistical nonparametric analysis indicated no significant differences in the concentrations of metals among the different classes of size in the organisms analyzed, although several authors have observed this relationship in field and laboratory studies (Boyden, 1974; Schulz-Baldes, 1974; Cunningham \& Tripp, 1975; Phillips, 1976a, 1976b).

In general, the concentrations of $\mathrm{Cu}, \mathrm{Cd}$ and $\mathrm{Pb}$ are low and similar to those found in non polluted areas of the Brazilian coast. 
TABLE 2

Concentrations of Cooper, Zinc, Lead and Cadmium in molluses from different areas of the Brazilian coast.

\begin{tabular}{|c|c|c|c|c|c|c|c|}
\hline Species & Site Banks & \multicolumn{2}{|c|}{ Source } & $\mathrm{Cu}^{*}$ & $\mathbf{Z n}^{*}$ & $\mathbf{P b} *$ & $\mathbf{C d}^{*}$ \\
\hline & & \multicolumn{2}{|c|}{ (Author/date) } & & & & \\
\hline C. brasilia & Estuary of Santos & CETESB & 1980 & 77.5 & - & - & - \\
\hline C. rhizophorae & $\begin{array}{c}\text { Straits of Coqueiros and } \\
\text { Mosquitos }\end{array}$ & Juras & 1985 & 41 & 1,560 & $<5.0$ & $<0.5$ \\
\hline M. falcata (small) & $"$ & $"$ & 1985 & 53 & 105 & $<5.0$ & $<0.5$ \\
\hline M. Falcata (medium) & $"$ & $"$ & 1985 & 47 & 81 & $<5.0$ & $<0.5$ \\
\hline M.falcata (large) & $"$ & $"$ & 1985 & 44 & 68 & $<5.0$ & $<0.5$ \\
\hline C. brasilia & Sepetiba Bay & Lima et al. & 1986 & - & $1,773-16,130$ & - & $1.5-28.2$ \\
\hline C. brasilia & $"$ & Pfeiffer et al. & 1985 & 3.2 & 973 & 1.1 & 1.60 \\
\hline C. rhizophorae & $"$ & $"$ & 1985 & 1,4 & 471 & 0.8 & 0.5 \\
\hline M. guianenis & $"$ & $"$ & 1985 & $1.0-2.2$ & $4.5-84.0$ & $0.4-2.1$ & $0.2-0.9$ \\
\hline P. perna & Praia Vermelha & Carvalho \& Lacerda & 1992 & 11.0 & 1,132 & 4.0 & 0.1 \\
\hline C.brasilia & $"$ & $"$ & 1992 & 148 & 1,302 & ñd & 0.4 \\
\hline P. perna & Boa Viagem & $"$ & 1992 & 99 & 169 & 1.0 & 0.1 \\
\hline P. perna & $"$ & Neira et al. & 1995 & 6.0 & 207.4 & 0.8 & - \\
\hline P. perna & Piratining & $"$ & 1995 & 6.9 & 79.9 & 0.8 & - \\
\hline P. perna & Itaipu & $"$ & 1995 & 6.2 & 134.9 & 0.8 & - \\
\hline P.perna & Itacoatiara & $"$ & 1995 & 8.1 & 183.5 & 0.8 & - \\
\hline
\end{tabular}


Zinc, on the other hand, showed slightly higher values than the maximum ones stablished to foods by the Brazilian Government. However, a more detailed study is recommended to associate the concentrations of this metal to a larger number of biometric and biological factors of this organism (sex and gonadal maturation) and environmental variables (salinity, $\mathrm{pH}$, seasonally).

Acknowledgments - We are grateful to João Reis Salgado Costa Sobrinho, for his valuable help rendered in the analyses by Atomic Absorption Spectrophotometry and To Prof. Dr. Claudio Urbano for reading the manuscript.

\section{REFERENCES}

ARAGÃO, M . do S. R. N., 1995, Determinação dos metais pesados $\mathrm{Zn}, \mathrm{Pb}$, Cd e Cu em águas da Lagoa da Jansen por Voltametria de Redissolução Potenciométrica. Univ. Fed. do Maranhão. (Monografia de Especialização), São Luís, 102p.

BOYDEN, C. R., 1974, Trace element content and body size in molluscs. Nature. Lond., 251: 311-314.

CARVALHO, C. E .V. \& LACERDA, L. D., 1992, Heavy metals in the Guanabara Bay biota: why such low concentrations? Ciência e Cultura. 44(2/3): 184-186.

CASTRO, A. C. L. de, 1991, Quantificação de Mercúrio total em tecido muscular do Dourado (Salminus maxillosus vallenciennes, 1849) do rio Mogi-guaçu, SP. Dissertação de mestrado, Escola de Engenharia de São Carlos, USP, $83 \mathrm{p}$.

CAVAlCANTE, P. R. S., DAMASCENO, R. N., MADDOCK, J. E. \& GOUVEIA, L. C., 1994, Determinação de $\mathrm{Cu}, \mathrm{Cd}, \mathrm{Pb}$ e Zn dissolvidos por Voltametria de Redissolução Potenciométrica: otimização. In: III Congresso Brasileiro de Geoquímica / I Congresso de Geoquímica dos Países de Língua Portuguesa, São Paulo, pp. 416-419.

CAVAlCANTE, P. R. S., COSTA, M. de L. \& TAROUCO, J.E.F., 1990, Avaliação preliminar dos níveis de Mercúrio da porção interna do Golfão Maranhense. In: Seminário Nacional de riscos e conseqüências do uso do Mercúrio. pp. $46-53$.

CETESB, 1980, Estudo de metais pesados no estuário da Baía de Santos. Relatório Final, 75p.

CUNNINGHAM, P. A. \& TRIPP, M. R., 1975, Factors affecting the accumulation and removal of mercury from tissues of the american oyster Crassostrea virginica. Mar. Biol., 31: 311-320.

EYSINK, G. G. J., 1988, Metais Pesados no Vale do Ribeira e em Iguape - Cananéia Ambiente, 2(1): 6-13.

JAGNER, D., 1982, Potentiometric stripping analysis. Analyst., 107: 593-599.

JAGNER, D. \& AREN, K., 1979, Potentiometric stripping analysis for $\mathrm{Zn}, \mathrm{Cd}, \mathrm{Pb}$ and $\mathrm{Cu}$ in sea water. Analytica Chimica., 107: 29-35.

JURAS, A. A., 1985, Metais pesados em Mytella falcata e Crassostrea rizophorae. In: UFMA/CIRM. Condições bióticas e abióticas do ambiente da Costa Maranhense. Relatório Final, São Luís, (mimeo.): 83-94.

JURAS, A. A., 1988, A preliminary survey of heavy metal concentration in some estuarine organisms in the littoral zone of São Luís Island, Maranhão, Brazil. In: Metals in coastal environments of Latin America. SpringerVerlag, Berlin, pp. 16-20.

LIMA, N. R. W., LACERDA, L. D., PFEIFFER, W. C. \& FIZMAN, M., 1986, Temporal and spatial variability in $\mathrm{Zn}, \mathrm{Cr}$, $\mathrm{Cd}$ and $\mathrm{Fe}$ concentrations in oyster tissues (Crassostrea brasiliana, Lamarck, 1819) from Sepetiba Bay, Brazil. Environmental Technology Letters, pp. $453-$ 460.

MOORE, J. W. \& RAMAMOORTHY, S., 1984, Heavy metals in natural waters applied monitoring and impact assessment. Springer-Verlag, New York, 268p.

NEIRA, U. M., WASSERMAN, J. C. \& YONESHIGUEVALENTIN, Y., 1995, Gradiente de poluição por metais pesados na Baía de Guanabara utilizando algas $e$ bivalves como indicadores. In: V Congresso Brasileiro de Geoquímica e III Congresso de Geoquímica dos Países de Língua Portuguesa, pp. 56-64.

PFEIFFER, W. C., LACERDA L. D. de \& FISZMAN, N. R. W., 1985, Metais pesados no pescado da Baía de Sepetiba, Estado do Rio de Janeiro. Ciência e Cultura, 37(2): 297-302.

PHILLIPS, D. J. H., 1976a, The common mussel Mytilus edulis as indicator of pollution by zinc, cadmiun, lead and copper. I. Effects of environmental variables on uptake of metals. Mar. Biol., 38: 59-69.

PHILLIPS, D. J. H., 1976b, The common mussel Mytilus edulis as indicator of pollution by zinc, cadmiun, lead and copper. II Relationship of metals in the mussel to those discharged by industry. Mar. Biol., 38: 71-80.

SCHULZ-BALDES, M., 1974, Lead uptake from sea water and food, and lead loss in the common mussel Mytilus edulis. Mar. Biol., 25: 177-193.

TALBOT, V., 1983, Lead and other trace metals in the sediments and selected biota of Princess Royal Harbour, Albany, Western Australia. Environmental Pollution, 5: 35-49. 